\title{
Changes in the phytoplankton community structure in a monomictic temperate lake
}

\author{
Alfredo Llorente and Sergio Seoane* \\ Department of Plant Biology and Ecology, University of the Basque Country (UPV/EHU), Leioa, 48940, Spain. \\ * Corresponding author: Sergio.seoane@ehu.es
}

Received: 05/11/18 Accepted: 26/09/19

\begin{abstract}
Changes in the phytoplankton community structure in a monomictic temperate lake

This study focused on the phytoplanktonic community of lake Sanabria (NW Spain) during the mixing period. We integrated the classic phytoplankton counting method and the pigment analysis via high performance liquid chromatography, to obtain a global image of the community structure, which was very similar among the study zones and unaltered despite a temporal increasing of biomass during this period. The diatom Asterionella formosa Hassall (around $80 \%$ ), and consequently the fucoxanthin were the species and the secondary pigment more abundant, respectively. This dominance contrasted with the studies performed in $90^{\prime}$ s, where the community structure was distributed among chlorophytes, cryptophytes, diatoms, dinoflagellates and cyanophytes, with no clear and persistent dominance of any of the main taxonomic groups and an occasional presence of Asterionella formosa. However, the classical variables, such as nutrients or chlorophyll $a$ concentration, used for trophic definition have barely changed since the studies of 90's. It is possible that other parameters, such as the residence time or the effect of the increase in the temperature since 90's could have influenced the phytoplankton community structural changes observed.
\end{abstract}

Key words: Asterionella formosa, diatoms, HPLC, pigments, Sanabria

\section{RESUMEN}

\section{Cambios en la estructura de la comunidad fitoplanctónica de un lago templado monomíctico}

El estudio se centró en la comunidad fitoplanctónica del Lago de Sanabria durante la época de mezcla. Se utilizaron, de manera integrada, el método clásico de recuento de fitoplancton y el análisis de pigmentos por cromatografía liquida de alta resolución (HPLC) para obtener una imagen general de la estructura de la comunidad, la cual resultó ser muy similar tanto espacial como temporalmente, a pesar de la existencia de un incremento estacional en la biomasa durante este periodo. La diatomea Asterionella formosa Hassall (en torno al $80 \%$ ) y, consecuentemente, la fucoxantina fueron la especie y el pigmento secundario más abundantes, respectivamente. Esta dominancia contrastó con los estudios realizados en la década de los 90 en los que se reflejaba que la estructura de la comunidad se repartía entre cloroficeas, criptoficeas, diatomeas, dinoflagelados y cianoficeas, sin que existiera una dominancia clara y persistente de ninguno de los grupos taxonómicos principales, y donde Asterionella formosa solo aparecía de manera ocasional. Sin embargo, las variables clásicas que definen el estado trófico, como la concentración de nutrientes o de clorofila a, no han sufrido apenas cambios. Es posible que otros parámetros, como el tiempo de residencia del agua o el efecto del incremento de la temperatura desde entonces, puedan tener relación con el cambio observado en la estructura de la comunidad fitoplanctónica.

Palabras clave: Asterionella formosa, diatomeas, HPLC, pigmentos, Sanabria 


\section{INTRODUCTION}

Phytoplankton is the basis of the trophic chain of aquatic autotrophic ecosystems. Hence, composition and dynamics of the phytoplankton community affect higher trophic levels (Reynolds, 1987), and the global functioning of the whole system. Traditionally, light intensity and availability of nutrients, particularly nitrogen and phosphorous, have been pointed as the main driving factors determining phytoplankton composition in lentic freshwater systems (Yang et al., 2008). In this sense, more recent studies tend to emphasize the importance of the synergistic effect that could exist within other ecological variables, such as the characteristics of the mixture (Becker et al., 2010). Phytoplankton stands out for its importance as an indicator of trophic and ecological status of water (Rakocevic-Nedovic \& Holler, 2005; Padisák et al., 2006; Pasztaleniec \& Poniewozik, 2010), and has become a key factor for eutrophication evaluation according to European institutions (OCDE 1982), culminating with the establishment of the Water Framework Directive (WFD 00/60/EC; EC Parliament and Council, 2000), which considered it as an indispensable tool for biomonitoring epicontinental water quality.

Knowledge of the phytoplankton community can be achieved through different techniques. From the classic microscopy ones, through pigment analysis or flow cytometry, to molecular based techniques. All of them have advantages and disadvantages; the integrated use of the maximum number of them can be used to obtain a realistic global image of the phytoplankton community. High-performance liquid chromatography (HPLC) allows the separation and quantification of pigments, such as chlorophylls and carotenoids, which, together with the specificity of some of these pigments for certain taxonomic groups, allows for inferences about the community through the application of chemotaxonomy. The use of this technique in freshwater is not so usual as it is marine or estuarine waters, (Descy et al.., 2009; Simmons et al., 2016), but it has shown effectiveness monitoring the phytoplankton community in lakes (Fietz \& Nicklisch, 2004; Descy et al., 2005; Picazo et al., 2013). HPLC allows rapid and automated analysis of lipophilic photosynthetic pigments (Jeffrey et al., 1999) with a high differentiating power of the higher taxonomic categories (Hou et al., 2011). On the other hand, microscopic techniques are able to discriminate at the level of genus or species, but present difficulties in the identification of nanoplankton and picoplankton, commonly well represented in oligotrophic systems, and also the reproducibility is lower than with chromatographic techniques (Goericke \& Montoya, 1998; Fietz \& Nicklisch, 2004).

Freshwater phytoplankton study stands out in lentic systems, particularly lakes and reservoirs that harbour well-structured resident communities. Lake Sanabria is the biggest natural lentic water system in Spain and the first limnological studies were developed in it at the beginning and the middle of 20th century (Taboada, 1913; Margalef, 1955). During the decade of the 1970s, a greater awareness for natural patrimony conservation arose; a special plan of landscaping was established and legal figures created, resulting in the declaration of the natural park of Lake Sanabria and surroundings in 1978. During the following decades, particularly during the 1990 s, scientific activity in the lake intensified (Aldasoro et al., 1991; Vega et al., 1992; De Hoyos, 1996; De Hoyos et al., 1998; De Hoyos \& Comín, 1999; Negro et al., 2000), with detailed descriptions of phytoplankton dynamics in this system. In the 21 st century the studies focused on natural and artificial systems of smaller size in the lake surroundings (Negro et al., 2003), sedimentary records (Luque \& Julià, 2002; Rico et al., 2007; Jambrina-Enríquez et al., 2014), and which established a retrospective comparison of the community (Pahissa et al., 2015).

In recent years, a social based polemic has taken place considering a study by Guillén, (2015), which integrates a series of reports and non-published investigations that question the oligotrophic or oligo-mesotrophic state of this mountain lake. These declarations have been strongly debated by the scientific community, which claimed its opposition based on detailed studies considering the trophic state of the lake (Aldasoro et al., 1991; Pahissa et al., 2015). Despite there being no well-founded evidence supporting either the contamination or the 


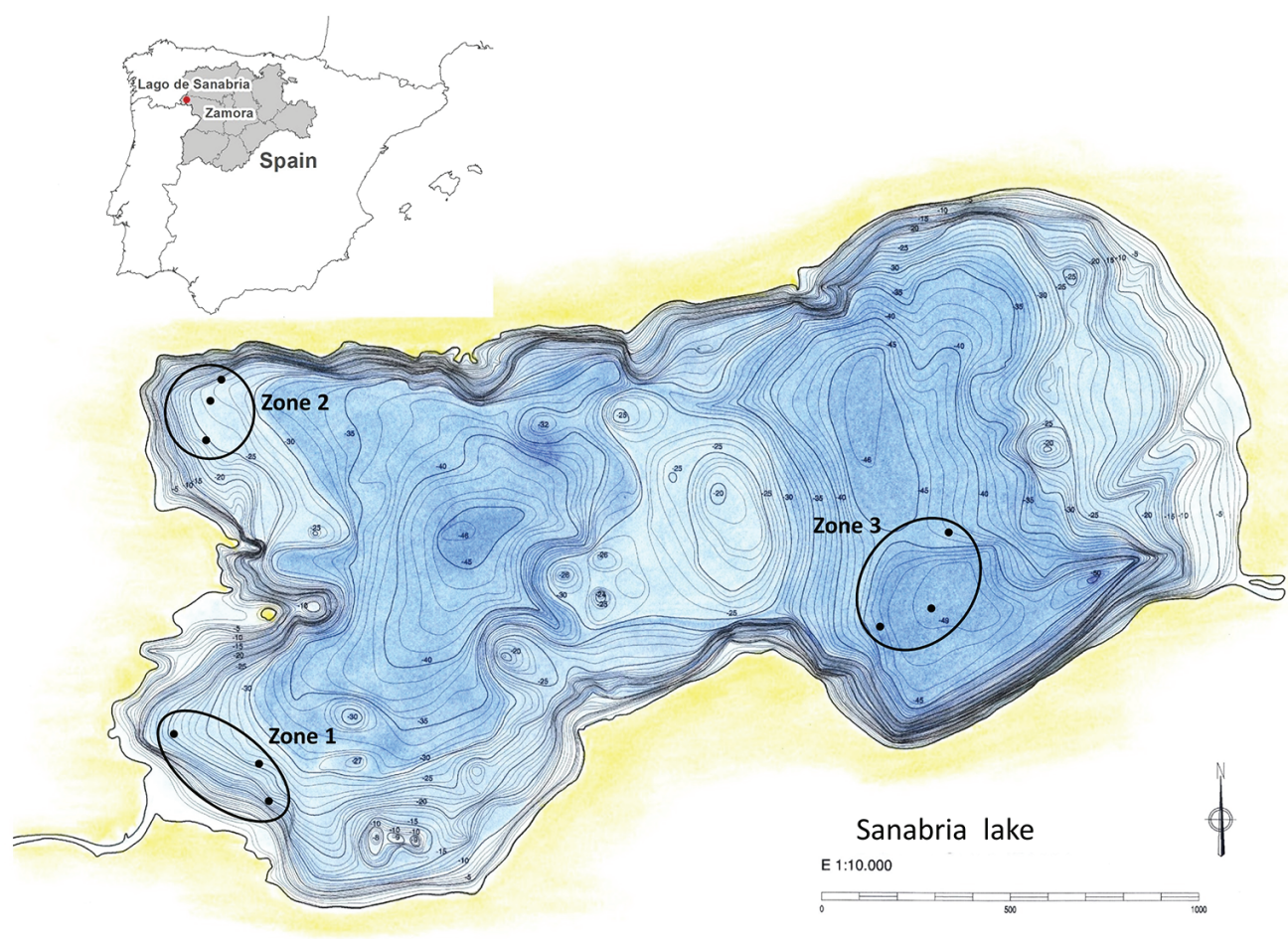

Figure 1. Sampling station map adapted from Vega et al. 2005. Sampling sites (black stars). Zone 1: stream input influence; Zone 2: livestock influence; Zone 3: lacustrine and reference zone. Mapa con las estaciones de muestreo adaptado a partir de Vega et al. 2005. Puntos de muestreo (estrellas negras). Zona 1: influencia de la pluma fluvial; Zona 2: influencia de la presencia de ganado; Zona 3: zona lacustre de referencia.

eutrophication of the lake, monitoring of the ecological variables seems to be advisable. Fires, change of land use in the catchment area, increase of nutrient imputes related to a higher human presence, along with a change of water turnover due to rather anthropic modifications of the course or actual climatic scenarios, imply a potential alteration of the lakes natural state. Therefore, the objectives of this work are to: $i$ ) characterize the phytoplankton community of Lake Sanabria during the mixing period (January-March), through the integrated use of chemotaxonomy (HPLC) and the classical phytoplankton counting method; ii) compare the phytoplankton community with that described in 90 's; iii) compare the community composition between three different zones, with varying threats regarding the nutrient supply, with the prediction of observing differences in the phytoplankton community between these zones.

\section{MATERIALS AND METHODS}

\section{Study site}

Lake Sanabria is located in the NW part of Spain ( $42^{\circ} 07^{\prime} 30^{\prime \prime} \mathrm{N}, 06^{\circ} 43^{\prime} 00^{\prime \prime} \mathrm{W}$ ), at $1000 \mathrm{~m}$ above sea level. It occupies a glacial depression of the Tera River valley, which belongs to the Duero River basin and originates at the confluence of the Segundera and Cabrera mountain ranges. Lake Sanabria has its origins in the last glaciation, through the morrenic closing of the valley. It is composed by two smaller basins separated by an intermediate threshold of depth (Aldasoro et al., 1991). The total area of the lake is 3.47 $\mathrm{km}^{2}$ and the volume is $96289887 \mathrm{~m}^{3}$. Other relevant morphometric parameters: maximum depth is found in the eastern basin with $51 \mathrm{~m}$, maximum width of $1530 \mathrm{~m}$ is observed across this basin, and the shoreline length is $9518 \mathrm{~m}$ 
(Vega et al., 2005). The lake is categorised within the Spanish typology as an acidic, deep, and middle mountain lake.

According to the characteristics of the mixing, Lake Sanabria is a warm monomictic and holomictic lake, with a mixing period generally extended from the ending of November, beginning of December, until March when water starts to stratify. In the winter months, an average homoeothermic state is found between 4 to $7^{\circ} \mathrm{C}$; while across stratification, an epilimnetic maximum temperature is observed around $24{ }^{\circ} \mathrm{C}$, during the month of August with a 1.7 ${ }^{\circ} \mathrm{C} / \mathrm{m}$ decrease in temperature throughout the metalimnion constituting the thermocline (Vega et al., 1992).

The geology of the lake is dominated by plutonic and metamorphic rocks (granite, quartzite and gneiss) conforming precipitous walls that end in a plane bottom. These materials, in absence of contamination, determine the oligotrophic state of the lake (Rico et al., 2007). Mineralisation is, therefore, low, with conductivity mean values near $14 \mu \mathrm{S} / \mathrm{cm}$, and $\mathrm{pH}$ values of approximately 6.5 , a slightly shifted equilibrium towards the acidic form of $\mathrm{CO}_{2}$. In addition, oxygen has a winter maximum concentration near $100 \%$ saturation without any anoxic period measured at any point of the year (De Hoyos, 1996). Within the threshold of oligotrophy, nutrient inputs come from three main sources: sediment resuspended during the winter mix, runoff from the basin through the main tributaries of the lake: Tera, Cardena, and Segundera rivers, and finally the discharges of anthropic origin that concentrate primarily during summer due to a greater tourist pressure particularly in the western basin, where Ribadelago is located (Aldasoro et al., 1991).

\section{Data collection}

Abiotic and biotic data collection took place from January to March (mixing period) of 2017. We decided to choose the mixing period, due to the homogeneity of the conditions along the whole study period, and trying to sample in the period of the year with the less human impact in the lake. A random sampling by zones was carried out, monthly and the data presented here are from January, February and March. The three zones studied were determined in order to detect areas of the lake exposed to possible sources of anthropic alteration (Zones 1 and 2) and without them (Zone 3 ). In addition, for its correct definition a bathymetric map was used (Fig. 1), avoiding areas near the shoreline and shallow depth. The first zone was chosen because of its proximity to the mouth of the river Tera after passing through the locality of Ribadelago, the second corresponded to the recent observations of livestock activity near the North-western shore margins. Finally, the third zone represents a strictly lacustrine area, which has been widely studied for harbouring the maximum depth, constituting a reference to the presumably unaltered state of the lake. Within each of these zones, three replicates $(\mathrm{A}, \mathrm{B}, \mathrm{C})$ were taken using a system of random choice of Cartesian coordinates.

In relation to the abiotic data, the maximum depth was measured with a laser meter; also, the depth of the Secchi disk was measured. Conductivity and $\mathrm{pH}$ were measured at each station in a single surface sample while oxygen concentration, percentage saturation, and temperature were measured at intervals of $0.5 \mathrm{~m}$ to five $\mathrm{m}$ depth, at intervals of one $\mathrm{m}$ from five to $20 \mathrm{~m}$, and at the points of greatest depth in intervals of five $\mathrm{m}$ from $20 \mathrm{~m}$ to the bottom. For this purpose, the probes corresponding to each variable (WTW: Multi350i; WTW: Oxi197) were used. Likewise, conductivity, temperature and $\mathrm{pH}$ were measured in the Tera River, at Ribadelago. As for the biotic data, surface direct water samples and net samples (both in the first $0.5 \mathrm{~m}$ depth) were taken for different purposes. Two hundred and fifty $\mathrm{mL}$ of direct samples were taken and fixed with one $\mathrm{mL}$ Lugol, while an approximate volume of $500 \mathrm{~mL}$ was preserved as a living sample in a Nalgene ${ }^{\circledR}$ bottle to observe alive the community in order to help with the identification. For the analysis of pigments, $5 \mathrm{~L}$ of water were taken in opaque bottles. Net samples were filtered through a $20 \mu$ $\mathrm{m}$ mesh, sweeping a similar surface at each sampling station for three minutes. The resulting sample was preserved both in vivo and fixed with Lugol. 


\section{Characterization of phytoplankton community}

\section{Microscopy}

The phytoplankton community was characterized from the Lugol-fixed surface samples following the Utermöhl method (Utermöhl, 1958) according to the WFD. Additionally, living subsamples of net and direct samples were observed under light microscopy at various magnifications to determine the presence of species that no resist well the fixation. For the $50 \mathrm{~mL}$ settled samples, cells were identified and counted under a Nikon Diaphot TMD (Nikon Corporation, Tokyo, Japan) inverted microscope. For the bigger-sized taxa, transects of $4 \mathrm{~cm}$ of the chamber area were examined at $100 \mathrm{x}$ magnification in each sample, collecting a minimum of at least 500 individuals of the dominant taxa; while for the smaller-sized taxa, two or three $\mathrm{cm}$ transects were examined at 400x magnification, reaching up to 50 individuals at least. Species biovolume was calculated using formulas from the Baltic Marine Environment Protection Commission (HELCOM; Olenina et al., 2006).

\section{High-performance liquid chromatography}

Water samples gathered for the pigment analysis were filtered with gentle vacuum $(<150 \mathrm{mmHg})$ onto Whatman GF/F glass-fibre filters (Whatman International Ltd.), filters were immediately

Table 1. Summary of superficial abiotic data from the vertical profiles of each replicate and month. ZSD: Secchi disk depth; Conduct: conductivity; Ox: oxygen concentration; Ox sat: oxygen saturation; T: temperature. Resumen de los datos abióticos superficiales extraídos de los perfiles verticales para cada replica y mes. ZSD: Profundidad disco de Secchi; Conduct: conductividad; Ox: concentración de oxígeno; Ox sat: saturación de oxígeno; T: temperatura.

\begin{tabular}{|c|c|c|c|c|c|c|c|c|c|c|}
\hline Month & $\begin{array}{c}\text { Sampling } \\
\text { zone }\end{array}$ & Hour & & ZSD & $\begin{array}{l}\text { Max. } \\
\text { Depth }\end{array}$ & $\begin{array}{l}\text { Conduct. } \\
(\mu \mathrm{S} / \mathrm{cm})\end{array}$ & $\mathrm{pH}$ & $\begin{array}{c}\text { Ox. } \\
(\mathrm{mg} / \mathrm{l})\end{array}$ & $\begin{array}{c}\text { Ox. Sat. } \\
\%\end{array}$ & $\mathrm{~T}\left({ }^{\circ} \mathrm{C}\right)$ \\
\hline \multirow{7}{*}{$\begin{array}{l}\text { JANUARY } \\
(24 / 01 / 2017)\end{array}$} & River & - & & - & - & 11 & 6.90 & - & - & 1.10 \\
\hline & 1 & $10: 10$ & Mean & 5.20 & 12.50 & 13.30 & 5.83 & 9.50 & 86.33 & 6.27 \\
\hline & & & SD & 0.26 & 4.17 & 0.96 & 0.32 & 0.10 & 0.58 & 0.06 \\
\hline & 2 & $11: 25$ & Mean & 5.00 & 18.40 & 11.47 & 5.85 & 9.50 & 86.33 & 6.40 \\
\hline & & & $\mathrm{SD}$ & 0.50 & 5.61 & 0.45 & 0.22 & 0.10 & 1.53 & 0.00 \\
\hline & 3 & $13: 30$ & Mean & 5.70 & 50.57 & 12.53 & 5.90 & 9.30 & 85.00 & 6.73 \\
\hline & & & $\mathrm{SD}$ & 0.61 & 1.33 & 1.56 & 0.17 & 0.10 & 1.00 & 0.15 \\
\hline \multirow{7}{*}{$\begin{array}{l}\text { FEBRUARY } \\
(22 / 02 / 2017)\end{array}$} & River & - & & - & - & 12.70 & 7.00 & - & - & 3.80 \\
\hline & 1 & $9: 48$ & Mean & 5.27 & 13.23 & 14.10 & 6.78 & 10.67 & 97.00 & 6.33 \\
\hline & & & SD & 0.25 & 4.16 & 2.44 & 0.19 & 0.06 & 0.00 & 0.06 \\
\hline & 2 & $10: 58$ & Mean & 5.00 & 20.37 & 15.23 & 6.60 & 10.63 & 97.00 & 6.57 \\
\hline & & & $\mathrm{SD}$ & 0.00 & 2.22 & 0.45 & 0.10 & 0.06 & 0.00 & 0.21 \\
\hline & 3 & $12: 37$ & Mean & 5.27 & 48.40 & 13.03 & 6.40 & 10.50 & 95.67 & 6.57 \\
\hline & & & $\mathrm{SD}$ & 0.21 & 2.87 & 0.87 & 0.17 & 0.00 & 0.58 & 0.15 \\
\hline \multirow{7}{*}{$\begin{array}{c}\text { MARCH } \\
(08 / 03 / 2017)\end{array}$} & River & - & & - & - & 8.70 & 6.40 & - & - & 4.10 \\
\hline & 1 & $9: 58$ & Mean & 5.23 & 14.70 & 12.80 & 6.03 & 10.93 & 96.33 & 5.60 \\
\hline & & & $\mathrm{SD}$ & 0.40 & 3.46 & 1.00 & 0.49 & 0.21 & 1.15 & 0.53 \\
\hline & 2 & $10: 59$ & Mean & 5.00 & 22.20 & 13.73 & 6.27 & 10.53 & 95.33 & 6.43 \\
\hline & & & SD & 0.00 & 4.25 & 2.35 & 0.46 & 0.06 & 0.58 & 0.15 \\
\hline & 3 & $12: 30$ & Mean & 5.47 & 48.20 & 12.73 & 6.30 & 10.53 & 97.33 & 6.75 \\
\hline & & & SD & 0.25 & 3.30 & 1.54 & 0.20 & 0.06 & 2.31 & 0.21 \\
\hline
\end{tabular}


frozen at $-80{ }^{\circ} \mathrm{C}$ until their analysis. Frozen filters were extracted under low light in three $\mathrm{mL}$ of 90 $\%$ acetone and ground with a glass stick for five min. The resulting slurry was filtered with a Teknokroma PTFE $(0.22 \mu \mathrm{m}$ pore size $)$ syringe filter (Teknokroma, S.C.C.L.), and the filtrate was kept refrigerated until analysis. Just before injection, $0.5 \mathrm{~mL}$ of extracts was diluted in 0.2 $\mathrm{mL}$ of distilled water to avoid peak distortion (Zapata \& Garrido, 1991). Pigments were analyzed by HPLC following the method of Zapata et al. (2000), modified by reducing 10 -fold the concentration of pyridine (final concentration $0.025 \mathrm{M}$ ) in eluent A (Seoane et al., 2009), using a Waters Symmetry C8 column $(150 \times 4.6 \mathrm{~mm}, 3.5 \mu \mathrm{m}$ particle size, $100 \AA$ pore size) (Waters Corporation) and a Waters 2996 photodiode array detector $(350-750 \mathrm{~nm} ; 1.2 \mathrm{~nm}$ optical resolution) interfaced with a Waters 2475 multi $\lambda$ fluorescence detector (Waters Corporation). Pigments were identified by their retention times and absorbance spectra. Retention times were compared with those of pure standards obtained commercially from DHI (Hoersholm) and those reported in Jeffrey (1997) and Zapata et al. (2000). HPLC calibration by external standard was performed using chlorophyll and carotenoids standards obtained commercially from DHI. The molar extinction coefficients obtained from Jeffrey (1997) were used for pigment quantification.

\section{Cultures and live samples}

Live samples and net samples were observed under light microscopy (100x, 200x and 400x magnifications) with the goal of facilitating the identification of the species that could not be well defined in the lugol-fixed samples. Also, cultures were stablished with this purpose, using $\mathrm{F} / 2$ culture medium (Guillard \& Ryther, 1962).

\section{Data treatment}

First, we analysed the dynamic of the phytoplankton community through the realisation of succession graphics (Microsoft ${ }^{\circledR}$ Excel $^{\circledR}$ 2011) for the higher taxonomic categories, and for the concentration of what we found to be the relevant pigments throughout the studied period. Mean values were included for each zone and month of study. The spatial and temporal variability of the multivariate compositional and pigment structure of assemblages were examined by a distancebased permutational multivariate analysis of variance (PERMANOVA, Anderson et al., 2008) considering composition and abundance of taxa, higher taxonomic categories, and pigments concentration. The experiment was designed with two factors: Month (random with three levels; January, February and March) and Zone (fixed with three levels; Zones 1, 2 and 3) with a significant level of $\alpha=0.05$. For both kinds of taxonomical analyses, data were square root transformed to balance the contributions of rare and dominant taxa and categories, while the Bray-Curtis index was used to determine similarity between pairs of samples. For pigment concentration, data was standardised by the maximum and an Euclidean distance matrix was generated. Also, Pearson correlations were carried out between the relevant pigments and the chlorophyll $a$. Finally, to visualise these results, samples were graphically organised through a multidimensional scaling (MDS) and Draftsman plot correlations were established between relevant pigments.

\section{RESULTS}

\section{Abiotic data}

The abiotic data are shown in Table 1. The maximum depth varied between $8.1 \mathrm{~m}$ at site $1 \mathrm{C}$ in January and $52 \mathrm{~m}$ at site $3 \mathrm{C}$ in March. Depth of the photic zone, calculated from Secchi disc, showed values in all areas around $14 \mathrm{~m}$, which in the zone 1 and in the first station of the zone 2 represents the whole column water, due to their depth minor than $14 \mathrm{~m}$. Conductivity ranged between 11 and $15.8 \mu \mathrm{S} / \mathrm{cm}$, with the values measured at the mouth of the Tera River being slightly lower, with a minimum value of $8.7 \mu$ $\mathrm{S} / \mathrm{cm}$ in March. In addition, $\mathrm{pH}$ presented values between 5.8 and 7 with a mean value of 6.21 . The concentration of oxygen, as well as the percentage of saturation, showed similar values, around 10 $\mathrm{mg} / \mathrm{L}$ and $90 \%$, respectively, being slightly lower in January than in February and March. Finally, the temperature presented values with a variation 
Table 2. Presence absence checklist of the species observed in the counts or in live samples. $1=$ presence and $0=$ absence Asterisks indicate rare taxa. Listado de presencia y ausencia de especies observadas en los recuentos o en las muestras no fijadas. Los asteriscos indican taxones infrecuentes.

\begin{tabular}{|c|c|c|c|c|c|c|c|c|c|}
\hline \multirow[b]{3}{*}{ CHLOROPHYTA } & \multicolumn{3}{|c|}{ January } & \multicolumn{3}{|c|}{ February } & \multicolumn{3}{|c|}{ March } \\
\hline & \multicolumn{3}{|c|}{ Zone } & & & & \multicolumn{3}{|c|}{ Zone } \\
\hline & 1 & 2 & 3 & 1 & 2 & 3 & 1 & 2 & 3 \\
\hline Ankistrodesmus falcatus (Corda) Ralfs & 1 & 1 & 1 & 0 & 1 & 1 & 1 & 0 & 0 \\
\hline Ankistrodesmus fusiformis Corda & 0 & 1 & 0 & 0 & 0 & 0 & 1 & 1 & 1 \\
\hline Ankistrodesmus sp. Corda* & 0 & 0 & 0 & 1 & 1 & 0 & 0 & 0 & 0 \\
\hline Ankistrodesmus spiralis (W.B.Turner) Lemmermann* & 0 & 0 & 0 & 0 & 0 & 0 & 1 & 0 & 0 \\
\hline Ankyra sp. Fott & 1 & 1 & 1 & 1 & 1 & 1 & 1 & 1 & 1 \\
\hline cf. Elakotothrix gelatinosa Wille* & 0 & 0 & 1 & 0 & 0 & 0 & 0 & 0 & 0 \\
\hline cf. Sphaerocystis schroeteri Chodat & 1 & 1 & 1 & 1 & 1 & 1 & 1 & 1 & 1 \\
\hline Chlamydomonas sp. Ehrenberg & 1 & 1 & 1 & 1 & 1 & 1 & 1 & 1 & 1 \\
\hline Crucigenia quadrata Morren & 1 & 1 & 1 & 1 & 1 & 1 & 1 & 1 & 1 \\
\hline Crucigenia tetrapedia (Kirchner) Kuntze & 1 & 1 & 1 & 1 & 1 & 1 & 1 & 1 & 1 \\
\hline Crucigeniella pulchra (West \& G.S.West) Komárek* & 0 & 0 & 0 & 0 & 0 & 0 & 1 & 1 & 0 \\
\hline Dictyosphaerium sp. Nägeli & 1 & 1 & 1 & 0 & 1 & 1 & 1 & 1 & 1 \\
\hline Elakatothrix gelifacta (Chodat) Hindák & 1 & 1 & 1 & 1 & 1 & 1 & 1 & 1 & 1 \\
\hline Gonium sp. O.F.Müller* & 0 & 0 & 0 & 0 & 0 & 1 & 0 & 0 & 1 \\
\hline Kirchneriella sp. Schmidle & 1 & 1 & 1 & 1 & 1 & 1 & 1 & 1 & 1 \\
\hline $\begin{array}{l}\text { Monoraphidium cf. contortum (Thuret) Komárková- } \\
\text { Legnerová }\end{array}$ & 1 & 1 & 1 & 1 & 1 & 1 & 1 & 1 & 1 \\
\hline Monoraphidium sp. Komárková-Legnerová & 1 & 1 & 1 & 1 & 1 & 1 & 1 & 1 & 1 \\
\hline Oocystis lacustris Chodat & 1 & 1 & 1 & 1 & 1 & 1 & 1 & 1 & 1 \\
\hline Oocystis sp. Nägeli ex A.Braun & 1 & 1 & 1 & 1 & 1 & 1 & 1 & 1 & 1 \\
\hline Pediastrum privum (Printz) Hegewald* & 0 & 0 & 0 & 0 & 0 & 0 & 0 & 0 & 1 \\
\hline Pediastrum tetras (Ehrenberg) Ralfs* & 1 & 0 & 0 & 0 & 0 & 0 & 0 & 0 & 1 \\
\hline Quadrigula closteroides (Bohlin) Printz & 1 & 1 & 1 & 0 & 1 & 1 & 1 & 1 & 1 \\
\hline Scenedesmus sp. Meyen* & 0 & 1 & 0 & 0 & 0 & 0 & 1 & 1 & $\overline{0}$ \\
\hline Tetradesmus obliquus (Turpin) M.J.Wynne & 0 & 0 & 0 & 0 & 0 & 0 & 0 & 1 & 0 \\
\hline Tetraedron caudatum (Corda) Hansgirg & 1 & 1 & 1 & 1 & 1 & 1 & 0 & 1 & 0 \\
\hline \multicolumn{10}{|l|}{ BACILLARIOPHYTA } \\
\hline Asterionella formosa Hassall & 1 & 1 & 1 & 1 & 1 & 1 & 1 & 1 & 1 \\
\hline Aulacoseira cf. granulata (Ehrenberg) Simonsen & 1 & 1 & 1 & 1 & 1 & 1 & 1 & 1 & 1 \\
\hline Aulacoseira distans (Ehrenberg) Simonsen & 0 & 0 & 0 & 0 & 0 & 1 & 0 & 0 & $\overline{0}$ \\
\hline Aulacoseira sp. Thwaites & 1 & 1 & 1 & 1 & 1 & 1 & 1 & 1 & 1 \\
\hline Centric diatom & 1 & 0 & 0 & 0 & 1 & 0 & 0 & 0 & 0 \\
\hline Centric diatom $100 \mu \mathrm{m}^{*}$ & 0 & 0 & 0 & 0 & 0 & 0 & 0 & 1 & $\overline{0}$ \\
\hline cf. Cyclotella sp. (chains) (Kützing) Brébisson* & 1 & 0 & 1 & 0 & 0 & 0 & 0 & 0 & 0 \\
\hline Cyclotella glomerata H.Bachmann & 1 & 1 & 1 & 1 & 1 & 1 & 1 & 1 & 1 \\
\hline Eunotia sp. Ehrenberg* & 0 & 0 & 0 & 0 & 1 & 0 & 1 & 1 & 1 \\
\hline Fragilaria cf. acus (Kützing) Lange-Bertalot* & 0 & 0 & 0 & 0 & 0 & 0 & 1 & 1 & 0 \\
\hline
\end{tabular}


Table 2. (cont.)

\begin{tabular}{|c|c|c|c|c|c|c|c|c|c|}
\hline & \multicolumn{3}{|c|}{ January } & \multicolumn{3}{|c|}{ February } & \multicolumn{3}{|c|}{ March } \\
\hline & \multicolumn{3}{|c|}{ Zone } & & & & \multicolumn{3}{|c|}{ Zone } \\
\hline \multicolumn{10}{|l|}{ BACILLARIOPHYTA } \\
\hline Fragilaria sp. Lyngbye* & 0 & 0 & 0 & 0 & 1 & 0 & 1 & 0 & 0 \\
\hline Gomphonema constrictum Ehrenberg* & 0 & 0 & 0 & 0 & 0 & 1 & 1 & 0 & 0 \\
\hline Navicula sp. Bory* & 0 & 0 & 1 & 0 & 1 & 1 & 0 & 0 & 0 \\
\hline Nitzschia sp. Hassall* & 0 & 0 & 1 & 1 & 0 & 0 & 1 & 0 & 0 \\
\hline Pennate diatom & 1 & 1 & 1 & 1 & 1 & 1 & 1 & 1 & 1 \\
\hline Pinnularia sp. Ehrenberg * & 0 & 0 & 0 & 0 & 0 & 0 & 1 & 0 & 0 \\
\hline Tabellaria fenestrata (Lyngbye) Kützing & 1 & 1 & 1 & 0 & 0 & 1 & 1 & 1 & 1 \\
\hline Tabellaria flocculosa (Roth) Kützing & 0 & 0 & 0 & 1 & 1 & 0 & 1 & 1 & 1 \\
\hline \multicolumn{10}{|l|}{ ZYGNEMATOPHYCEAE } \\
\hline Closterium sp. Nitzsch ex Ralfs & 1 & 0 & 0 & 0 & 1 & 1 & 0 & 0 & 1 \\
\hline Cosmarium cf. contractum O.Kirchner & 1 & 1 & 1 & 1 & 1 & 1 & 1 & 1 & 1 \\
\hline Euastrum ansatum Ehrenberg ex Ralfs* & 0 & 0 & 0 & 0 & 0 & 1 & 0 & 0 & 0 \\
\hline Mougeotia sp. C.Agardh* & 0 & 0 & 1 & 0 & 0 & 0 & 0 & 0 & 0 \\
\hline Spondylosium planum (Wolle) West \& G.S.West & 1 & 1 & 1 & 1 & 1 & 1 & 1 & 1 & 1 \\
\hline Staurastrum anatinum Cooke \& Wills & 1 & 1 & 1 & 1 & 1 & 1 & 1 & 0 & 1 \\
\hline Staurastrum brachiatum Ralfs ex Ralfs & 0 & 0 & 1 & 1 & 0 & 1 & 1 & 1 & 1 \\
\hline Staurastrum paradoxum Meyen ex Ralfs* & 0 & 0 & 0 & 0 & 0 & 1 & 0 & 0 & 0 \\
\hline Staurodesmus sp. Teiling & 1 & 1 & 1 & 1 & 1 & 1 & 1 & 1 & 1 \\
\hline Xanthidium antilopaeum Kützing & 0 & 0 & 0 & 0 & 0 & 0 & 0 & 0 & 0 \\
\hline \multicolumn{10}{|l|}{ CYANOBACTERIA } \\
\hline Anabaena sp. Bory ex Bornet \& Flahault & 1 & 1 & 0 & 0 & 1 & 1 & 1 & 1 & 1 \\
\hline cf. Oscillatoria sp. Vaucher ex Gomont & 0 & 0 & 0 & 0 & 0 & 1 & 1 & 0 & 0 \\
\hline Chroococcus minutus (Kützing) Nägeli & 1 & 1 & 0 & 0 & 1 & 1 & 1 & 1 & 1 \\
\hline Cyanotetras crucigenielloides Komárek & 1 & 1 & 0 & 0 & 1 & 1 & 1 & 0 & $\overline{0}$ \\
\hline Merismopedia glauca (Ehrenberg) Kützing* & 0 & 0 & 1 & 0 & 0 & 0 & 0 & 0 & 0 \\
\hline undefined cocoids & 1 & 1 & 0 & 0 & 1 & 1 & 1 & 1 & 1 \\
\hline \multicolumn{10}{|l|}{ CHRYSOPHYCEAE } \\
\hline Bitrichia sp. Woloszynska* & 0 & 0 & 0 & 1 & 1 & 0 & 1 & 1 & 0 \\
\hline Dinobryon bavaricum Imhof* & 1 & 1 & 0 & 1 & 0 & 0 & 0 & 0 & 0 \\
\hline Dinobryon divergens O.E.Imhof & 1 & 1 & 1 & 1 & 1 & 1 & 0 & 0 & 1 \\
\hline Mallomonas sp. 1 Perty & 1 & 1 & 0 & 0 & 1 & 1 & 1 & 1 & 1 \\
\hline Mallomonas sp. 2 Perty & 0 & 0 & 0 & 0 & 0 & 0 & 0 & 0 & 1 \\
\hline \multicolumn{10}{|l|}{ CRYPTOPHYTA } \\
\hline Cryptomonas cf. erosa Ehrenberg & 1 & 1 & 1 & 1 & 1 & 1 & 1 & 1 & 1 \\
\hline Cryptomonas cf. marssonii Skuja & 1 & 1 & 1 & 1 & 1 & 1 & 1 & 1 & 1 \\
\hline $\begin{array}{l}\text { Plagioselmis nannoplanctica (H.Skuja) G.Novarino, } \\
\text { I.A.N.Lucas \& S.Morrall }\end{array}$ & 1 & 1 & 1 & 1 & 1 & 1 & 1 & 1 & 1 \\
\hline \multicolumn{10}{|l|}{ DINOPHYTA } \\
\hline Peridinium sp. Ehrenberg* & 0 & 0 & 0 & 1 & 0 & 0 & 0 & 0 & $\overline{0}$ \\
\hline Peridinium umbonatum Stein* & 0 & 0 & 0 & 0 & 0 & 1 & 0 & 0 & 0 \\
\hline
\end{tabular}


lower than $2{ }^{\circ} \mathrm{C}$, presenting a tendency to superficial heating of the water in the samples taken towards noon. The results of the environmental variables showed a clear mixing of the water.

\section{Biotic data}

From the microscopic identification of the samples, 72 different taxa were found (Table 2). In this way, the microscopic analysis of the community identified the Chlorophyta division as the best represented with a total of 25 taxa, followed by diatoms (Bacillariophyta division) with 19 taxa. In relation to the biovolume (Fig. 2), considerable spatial and temporal homogeneity in the structure of the community with a progressive increase in the total biovolume from January to March was observed. Diatoms, contributed most of this increasing biovolume, specifically the species Asterionella formosa Hassall, which dominated the community with a percentage of contribution in biovolume temporarily increasing from 70 to $85 \%$. Other diatoms observed were the taxa: Aulacoseira sp. Thwaites, Tabellaria fenestrata (Lyngbye) Kützing, and Tabellaria flocculosa (Roth) Kützing. Likewise, a centric diatom with about $100 \mu \mathrm{m}$ of diameter stands out for its exclusive presence in the 2C March sample, notably increasing the total biovolume of the diatoms in this particular area (Fig. 2). As for the rest of the higher taxonomic groups, the green algae followed the diatoms in biovolume, underlining taxa such as: Monoraphidium sp. Komárková-Legnerová, Crucigenia tetrapedia (Kirchner) Kuntze, Crucigenia quadrata Morren, or Oocystis lacustris Chodat for chlorophytes and taxa such as Staurodesmus sp. Teiling, Staurastrum anatinum Cooke \& Wills, Cosmarium cf. contractum O.Kirchner, or Spondylosium planum (Wolle) West \& G.S. West for the desmids. The other taxonomic groups maintained low biovolumes, but were nevertheless considerable in terms of the number of cells per L. Taxa such as Plagioselmis nannoplanctica (H.Skuja) G.Novarino, I.A.N.Lucas \& S.Morrall (Cryptophyta), Chroococcus minutus (Kützing) Nägeli (Cyanobacteria), or Dinobryon divergens O. E.Imhof (Chrysophyceae) were the most abundant in these

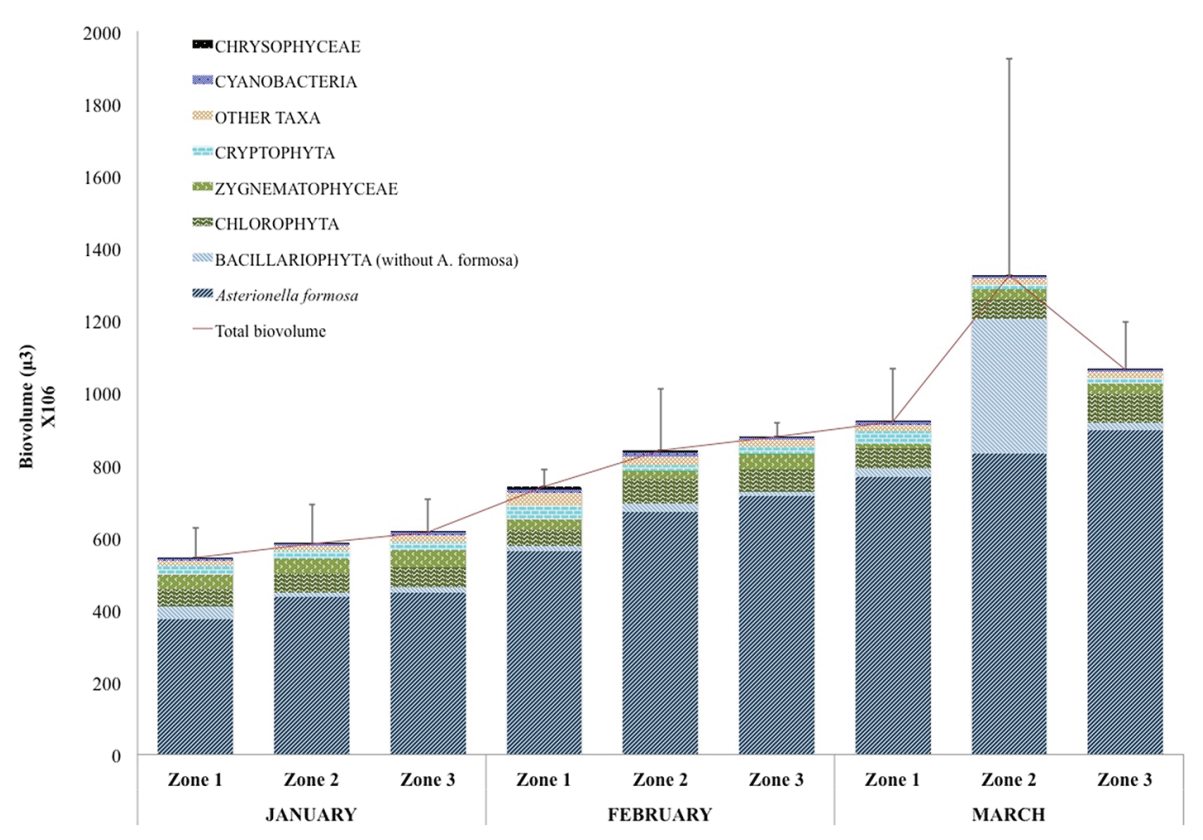

Figure 2. Phytoplankton community succession in terms of biovolume $\left(\mu \mathrm{m}^{3}\right)$ throughout the months of study. Mean values of the higher taxonomic groups are included for each zone. Sucesión de la comunidad fitoplanctónica en términos de biovolumen ( $\mu m^{3}$ ) a través de los meses de estudio. Se incluyen los valores medios de los grupos taxonómicos superiores. 
other groups. We also found that the sample taken in December (data not shown) were also totally dominated by $A$. formosa, and the dominance continued in the same year in August (unpublished data).

Regarding the results of the pigment analysis by HPLC, the values of chlorophyll $a$ ranged between $1.7 \mu \mathrm{g} / \mathrm{L}$ in the zone 3 in January and 3.5 $\mu \mathrm{g} / \mathrm{L}$ in the zone 2 in March. In addition to the chlorophyll $a$, we found four relevant pigments that dominated the community along the entire period: fucoxanthin, chlorophyll $b$, lutein, and alloxanthin (Fig. 3). Fucoxanthin stands out among the other accessory pigments, sharing a similar pattern to chlorophyll $a$ (Fig. 4), and showing the influence of diatoms on the variation of chlorophyll $a$ and, therefore, on the total biomass of the system. According to Pearson correlations, the only significant case found was between chlorophyll $a$ and fucoxanthin. Chlorophyll $b$ and lutein experienced a decrease from January to February and March, while alloxanthin maintained slightly lower concentrations in all areas and over the months, with values around $1.3 \times 10^{-4}$ and $5.9 \times 10^{-5} \mu \mathrm{mol} / \mathrm{L}$.

PERMANOVA detected significant differences for the month factor in the three cases studied. However, significant differences were not observed for the Zone factor (Table 3). The MDS reflects the spatial arrangement of the samples for the month factor, considering the composition and abundance of taxa. The grouped samples can be discriminated according to each of the three months studied (January-March). The eccentric position of the M2C sample of March mainly responds to the high biomass of a rare taxa, a $100 \mu \mathrm{m}$ undefined diatom. (Fig. 5).

Considering the relevant pigment concentration $(\mu \mathrm{mol} / \mathrm{L})$ according to the Month factor (Fig. 6 ), it can be seen how it coincided with the analyses previously presented. January samples remain even more isolated from the rest, forming a perfectly distinguishable group; while a smooth transition between February and March samples is observed, being less scattered and jumbled than in the case of the composition and abundance of taxon analyses. Also, in figure 6 the deviation of sample M2C (March) appears to be less pronounced than in Figure 5.

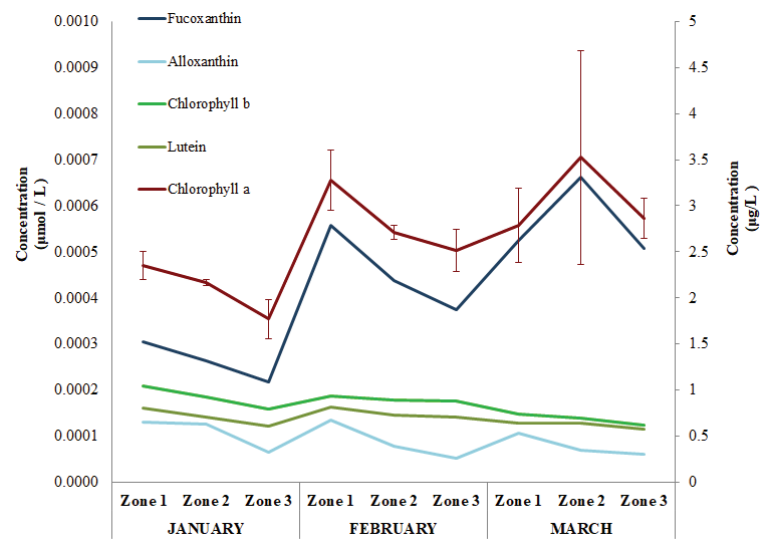

Figure 3. Pigmentary succession of the phytoplankton community. Mean concentration $(\mu \mathrm{mol} / \mathrm{L})$ values are shown for the most relevant pigments: fucoxanthin, alloxanthin, chlorophyll $b$, and lutein, while chlorophyll $a$ is presented in $\mu \mathrm{g} / \mathrm{L}$ concentration values in a secondary axis together with its standard deviation values. Sucesión pigmentaria de la comunidad fitoplanctónica. Se presentan los valores de las concentraciones medias $(\mu \mathrm{mol} / \mathrm{L})$ de los pigmentos más relevantes: fucoxantina, aloxantina, clorofila b y luteina, mientras que la concentración de clorofila a se presenta en el eje secundario en $\mu \mathrm{g} / \mathrm{L}$ junto con sus valores de desviación estándar.

Finally, these results show the existence of a significantly homogeneous community at the spatial scale for the studied zones, in combination with a temporal rise in chlorophyll $a$ that seems to be associated with an increase in the total biovolume of the samples, despite maintaining the general structure of the community.

\section{DISCUSSION}

The marked dominance of $A$. formosa contrasts with what was previously expected from the biological quality reports that have been carried out by the Duero hydrographic confederation (CHD, http://www.mirame.chduero.es). Since the monitoring started in 2006, this species began to appear in net samples corresponding to May 2010, as well as in the counts of July 2013 and September 2016 campaigns, and in both cases the abundance remained two orders of magnitude below the values detected in this study. In addition, De Hoyos et al. (1999) did not mention it as one of the dominant diatoms in their study about the phytoplankton community in their study 
which spanned for three years, and, finally Pahissa et al. (2015), even showed that diatoms were the dominant group in summer period, it was due to the presence of Aulacoseira and $T$. flocculosa. Not only Asterionella formosa's abundance has been totally different to the past studies, also the dominance of diatoms contrasts with some reference works (Aldasoro et al., 1991; De Hoyos, 1996, 1999; Negro et al., 2000) that reflect that diatoms do not seem to have ever dominated the community, maintaining until 2012 low abundances of fundamentally centric

Table 3. Main results of the PERMANOVA test to evaluate the effect of the factors Zone and Month on the composition and abundance of taxa, higher taxonomic categories, and concentration of pigments $(\mu \mathrm{mol} / \mathrm{L}) . P$ value that was considered significant $p<$ 0.05. Resultados principales de la prueba PERMANOVA para evaluar el efecto de los factores Zona y Mes para la composición y abundancia de taxones, categorías taxonómicas superiores y concentración de pigmentos $(\mu m o l / L)$.

\begin{tabular}{|c|c|c|c|c|}
\hline \multicolumn{5}{|c|}{ Composition and abundance of taxa } \\
\hline Source & Df & MS & Pseudo-F & $P$ \\
\hline Zone & 2 & 277.44 & 0.9239 & 0.5892 \\
\hline Month & 2 & 1323.70 & 5.9465 & 0.0001 \\
\hline Residual & 18 & 222.61 & & \\
\hline \multicolumn{5}{|c|}{ Higher taxonomic categories } \\
\hline Source & Df & MS & Pseudo-F & $P$ \\
\hline Zone & 2 & 91.179 & 2.1334 & 0.1002 \\
\hline Month & 2 & 458.400 & 14.9230 & 0.0001 \\
\hline Residual & 18 & 30.717 & & \\
\hline \multicolumn{5}{|c|}{ Pigments } \\
\hline Source & Df & MS & Pseudo-F & $P$ \\
\hline Zone & 2 & 4.4175 & 2.6776 & 0.0813 \\
\hline Month & 2 & 71.9350 & 73.8060 & 0.0001 \\
\hline Residual & 18 & 0.9746 & & \\
\hline
\end{tabular}

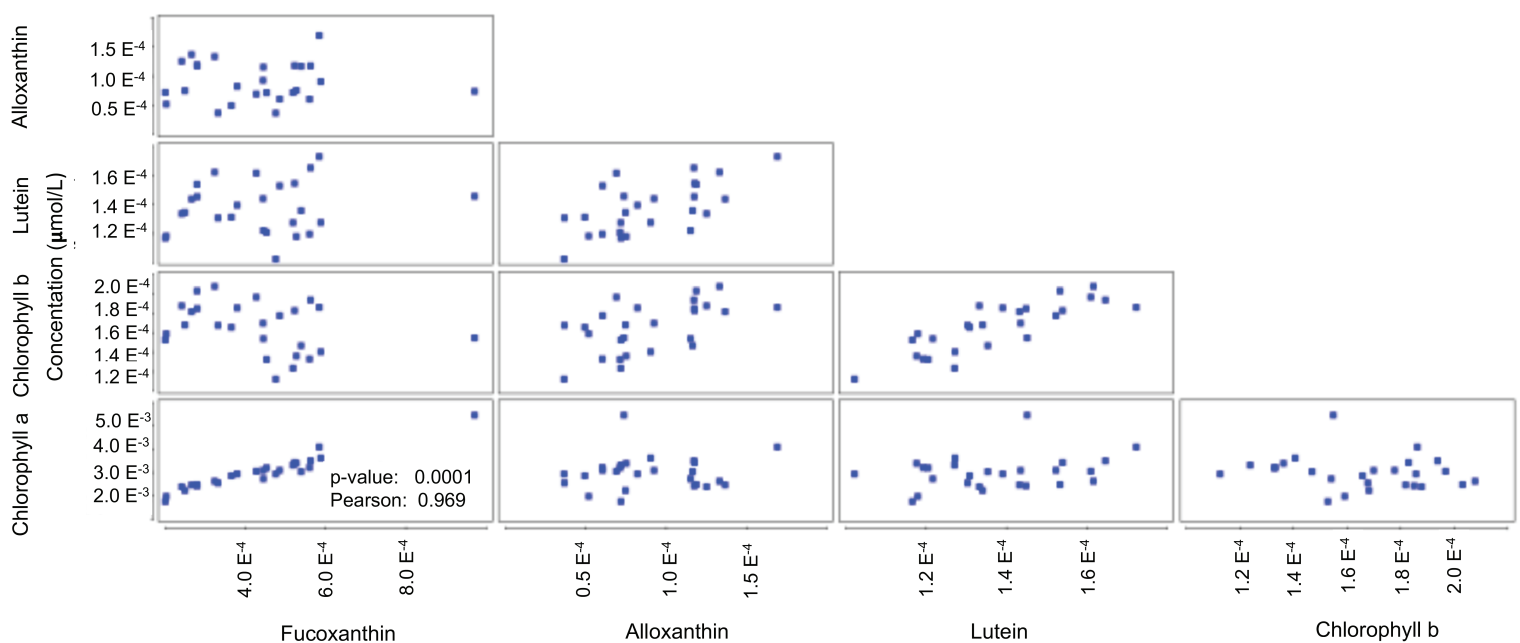

Figure 4. Draftsman plot correlations between chlorophyll $a$ and the rest of the significant pigments: fucoxanthin, alloxanthin, lutein, and chlorophyll $b$. Pearson correlation and $p$ values are shown for the unique case that presented significance; between chlorophyll $a$ and fucoxanthin. Correlaciones Draftsman plot entre la clorofila a y el resto de los pigmentos mayoritarios: fucoxantina, aloxantina, luteína y clorofila b. Los valores de la correlación de Pearson, así como el p-valor se presenta únicamente en la correlación que resultó significativa; entre la clorofila a y la fucoxantina. 
species like Aulacoseira distans (Ehrenberg) Simonsen or Cyclotella glomerata H. Bachmann. However, A. formosa has been detected since 90 's in water bodies associated with the lake. In the period 1991-1992, it presented a contribution of more than $0.5 \%$ of the Valparaíso reservoir, located downstream of the lake (Negro et al., 2000). It was also identified in some other small natural water systems in its geological environment (Negro et al., 2003), so translocation phenomena may have happened.

The absence of significant differences for the zone factor during the months of study for both taxonomic and pigmentary analyses suggests spatial homogeneity, qualitatively and quantitatively, in the general structure of the phytoplankton community. Highly contrasting with what was initially expected from the Aldasoro et al. (1991) study that proposed a seasonal controlled patchiness for the horizontal distribution of chlorophyll $a$. This homogeneity was slightly altered by the differential appearance of minority taxa, frequently lowly represented in terms of biovolume. In this context, the exception was the exclusive appearance of the centric diatom of $100 \mu \mathrm{m}$ of diameter in the sample 2C of March. This alga presented a moderate cell/L concentration; however, due to the large average diameter of the individuals, the biovolume that is explanatory for the total system biomass (Felip \& Catalan, 2000) obtained very high values, close to those of Asterionella. The fact that it only appeared in one of the nine samples of March could imply the necessity of a greater random replication in order to reach a greater degree of knowledge of the structural complexity of the community and, presumably, independently of the contemplated zone factor in this study. Likewise, although the water mixture is intense and complete, minimising the possibilities of niche diversification in the planktonic zone (Jäger et al., 2008), the performed analysis only examined the surface of the water column. Integrated sampling could lead to more faithful results to extrapolate to the whole planktonic area. Regarding the month factor, in all cases, the differences were greater between January and the other two months of study, that presented more similar values. However, for the three performed data analyses, increasing values of biovolume and

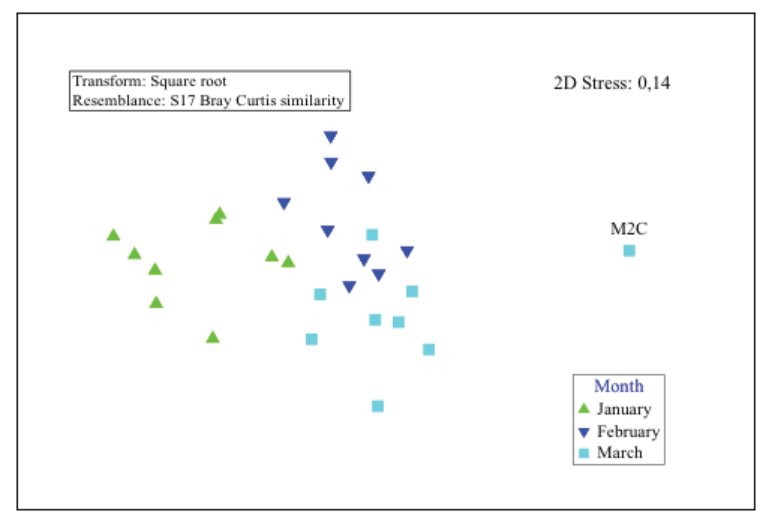

Figure 5. Multidimensional scaling for the composition and abundance of taxa. Disposition of samples is shown for the Month factor. $\mathrm{M} 2 \mathrm{C}=$ Sample $\mathrm{C}$ from zone 2 in March. Análisis de escalamiento multidimensional para la composición y abundancia de los taxones. La disposición de las muestras se presenta para el factor Mes. M2C = Muestra C de la zona 2 del mes de marzo.

chlorophyll $a$ were detected from January to March, which suggested a temporary change over the mixing period in the system biomass. The observed correlation between chlorophyll $a$ and fucoxanthin (Fig. 4) corresponds to the detected increase in $A$. formosa. In contrast to the availability of nutrients offered by water mixing, this fact could point towards the change in solar radiation as the main potential driving factor that would condition this increase in biomass.

Since 2012 a series of unpublished statements, supported by the Douro international biological station (EBI), later collected in the self-published monograph (Guillén, 2015), have been warning of a supposed contamination and eutrophication process of Lake Sanabria. These declarations exposed some supposed symptoms that alluded to a loss of quality in the physical and chemical state of the water, which was mainly identified through a change in water colouration that, as it is affirmed, would have concerned a deficient depuration system of the sewage. This deficiency may have contributed to the excessive growth of $T$. fenestrata and its pronounced dominance until the end of period 2012-2014, when it seemed to drastically remit, supposedly due to a chytrid infestation of this dominant alga. This sudden dominance appeared to be backed up by the 


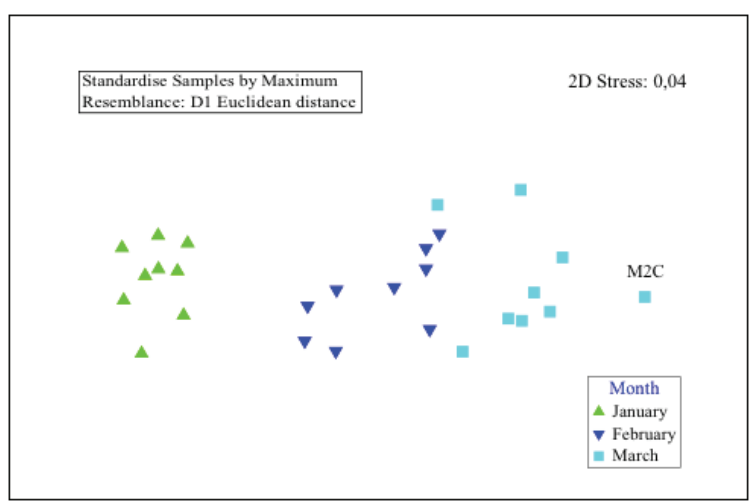

Figure 6. Multidimensional scaling for the pigment concentration. Disposition of samples is shown for the Month factor. M2C = Sample C from zone 2 in March. Análisis de escalamiento multidimensional para la concentración pigmentaria. La disposición de las muestras se presenta para el factor Mes. M2C = Muestra $C$ de la zona 2 del mes de marzo.

reports of the CHD during this period. Apart from the dominance of $T$. fenestrata, Guillén (2015) points out some other irregularities in the community in comparison to the period 1987-1989 studied by De Hoyos (1996). Among these irregularities during the period 2012-2014, a complete disappearance of chrysophytes and cryptophytes, a negligible presence (less than $1 \%$ ) of the chlorophytes (chlorophyceae) and continued presence of euglenophytes were observed. In addition, a lack of presence of conjugated algae, abundant in these acidic water bodies, with the replacement of $S$. anatinum by an indicator of mesotrophy, such as Staurastrum pingue Teiling, was also noted. All of these observations would lead to an impoverishment in the biodiversity of the phytoplanktonic community, altering the trophic chains and, eventually, affecting the global ecological quality status of the lake.

As for the general community structure, we did not fully share the observations described in Guillen (2015); in fact, although the dominance of diatoms persists, fundamentally to the detriment of the abundance of green algae, which obviously means that a great change in the general structure of the community has taken place in comparison to the period 1987-1989, the general composition of the rest of the taxonomic groups found in this study remains intermediate between the period 1987-1989 and the period 2012-2014. Despite their low abundance, chrysophytes remained present during the whole study, particularly the genus Mallomonas Perty. Cryptophytes are well represented in terms of cell $/ \mathrm{mL}$ through the genus Cryptomonas Eherenberg and the species $P$. nannoplanctica, which holds an average concentration of approximately 30 cell $/ \mathrm{mL}$. The chlorophyceae class reaches up to $7 \%$ of the global biovolume average, being the best represented in terms of number of species, the conjugated algae were always present constituting the $4 \%$ of the global biovolume average of the study period, standing out over taxa such us: Staurodesmus, S. planum, or S. anatinum. Finally, we did not identify the presence of euglenophytes. All of these observations could suggest a tendency to the return of the previous conditions after a drastic structural change or a completely new adjustment in the community structure.

About the diagnostic variables measured during this study, $\mathrm{pH}$ maintained the expected values, with a slight tendency to acidity, due to the characteristics of the geological environment. Mean conductivity in the lacustrine zone was $12.6 \mu \mathrm{S} / \mathrm{cm}$, close to the $14.6 \mu \mathrm{S} / \mathrm{cm}$ mean value registered by Vega et al. (1992). Global mean of Secchi disk depth, 5.20, remained in the mesotrophic threshold (6-3) (OCDE, 1982), despite not being the most accurate variable due to its inverse relation to turbulence and suspended matter. Mean chlorophyll $a$ went from $2.09 \mu \mathrm{g} / \mathrm{L}$ in January to $3.05 \mu \mathrm{g} / \mathrm{L}$ average in March, which is between the oligotrophy and the oligomesotrophy thresholds. As for other relevant data, values of total phosphorus contributed by the CHD presented a concentration of $6.7 \mu \mathrm{g} / \mathrm{L}$ PT in September 2016 and $11.4 \mu \mathrm{g} / \mathrm{L}$ PT in July 2016, values slightly higher than those detected at the origin of these reports of CHD. These values are below the threshold limit of oligotrophy $(<10 \mu$ $\mathrm{g} / \mathrm{L}$ ) in September, slightly higher in July, in the transition to the expected values for a mesotrophic system. Despite not being able to provide the annual means as advisable when defining the trophic status, these data do not seem to reflect a notorious process of contamination or eutrophication at present, much less a true loss of the natural state of the lake. 
The presence of $A$. formosa and other pennate diatoms has classically been associated with eutrophication processes, thriving when nutrient supply increases (Olsén \& Willén, 1980; Reynolds, 2000). In the case of A. formosa, some studies relate its increased abundance with an increase in nitrate (Bozniak \& Kennedy, 1968) and phosphate levels (Bigler et al., 2007). Nevertheless, this alga can be frequently found in temperate water bodies of different trophic states (Negro et al., 2000; Wyngaert et al., 2015), which may question the diagnostic capabilities of their autoecological features. Bertrand et al. (2003) elaborated a detailed study of the responses of $A$. formosa to environmental factors in a reservoir complex, indicating that the main conditioning to the appearance of the species were the morphometric features and the retention time of the system. In addition, they observed a great negative relation of its presence to turbulence and hydrodynamics with preference for lower temperatures $\left(<\right.$ eight $\left.{ }^{\circ} \mathrm{C}\right)$ and low phosphate levels $(<$ one $\mu \mathrm{g} / \mathrm{L})$. Variables not contemplated in this study, such as the characteristics and frequency of the mixing episodes as well as the rate of water renewal could be influencing the dynamics of the community (Lindenschmidt \& Chorus, 1998; De Hoyos \& Comín, 1999; Bertrand et al., 2003). In fact, comparing the residence times of the water exposed in De Hoyos \& Comín (1999), from 1942 to 1992 , with the values of the last years (Vega pers. comm.), it can be observed that the residence time is almost double, with 0.76 years as the average of the period 1942-1992 and 1.31 years in the last five years before our sampling. Likewise, timing alterations on the phytoplanktonic dynamics due to extreme inter-annual alterations in the climate, like time series of winter NAO (North Atlantic Oscillation) index could be triggering a response in phytoplankton (Weyhenmeyer et al., 2001, 2002). Most of the lake rainfall is due to Atlantic fronts during winter, which with a relatively high inter-annual variability are strongly controlled by NAO (Visbeck et al., 2001; Trigo et al., 2002, 2004) in this particularly sensitive Northwest Iberian Peninsula (Jambrina-Enriquez et al., 2014). These facts added to the global change frame where drought episodes, change of land use, and fires are becoming more frequent and could be creating a completely new scenario of environmental factors that are to be seriously taken into account.

Overall, a new structure of the phytoplankton community has been observed in Lake Sanabria during the mixing period of 2017, but not substantial changes in the classic and diagnostic variables of the trophic state, that can advise of an alteration of the ecological status compared with the communities described in the 1990's and with those reported for routine monitoring. A homogeneity of the general structure of the community along the period and at the three different selected zones has been noted, discarding the human impact at least in the winter period. We suggest further and continuous monitoring of this important ecosystem and contemplate the effect that other ecological variables such as changes in hydrodynamics and climate change could produce.

\section{ACKNOWLEDGEMENTS}

We are grateful to the hydrographic confederation of the Duero River (Confederación Hidrográfica del Duero, CHD) for providing historic and current data. We also wanted to thank to Junta de Castilla y León, particularly to Jesús Palacios, for the facilities given to carry out research in the Natural Park of Lake Sanabria, and to Jose Carlos Vega for his logistic help in the samplings and for making available to us his invaluable knowledge about this fascinating ecosystem.

\section{REFERENCES}

ALDASORO, J. J., C. DE HOYOS \& J. C. VEGA. 1991. El lago de Sanabria: Estudio limnológico. Zamora: Consejería de Medio Ambiente y Ordenación del Territorio.

ANDERSON, M. J., R. N. GORLEY \& K. R. CLARKE. 2008. PERMANOVA+ for PRIMER: Guide to Software and Statistical Methods. PRIMER-E, Plymouth, 214 pp.

BECKER, V., L. CAPUTO, J. ORDÓÑEZ, R. MARCÉ, J. ARMENGOL, L. O. CROSSETTI \& V. L. M. HUSZAR. 2010. Driving factors of the phytoplankton functional groups in a deep Mediterranean reservoir. Water Research, 44: 3345-3354. DOI: 10.1016/j. 
watres.2010.03.018

BERTRAND, C., S. FAYOLLE, E. FRANQUET \& A. CAZAUBON. 2003. Responses of the planktonic diatom Asterionella formasa Hassall to abiotic environmental factors in a reservoir complex (south-eastern France). Hydrobiologia, 501: 45-58. DOI: 10.1023/ A:1026251101534

BIGLER, C., L. VON GUNTEN, A. F. LOTTER, S. HAUSMANN, A. BLASS \& C. OHLENDORF. 2007. Quantifying human-induced eutrophication in Swiss mountain lakes since AD 1800 using diatoms. Holocene, 17 (8): 1141-54. DOI: 10.1177/0959683607082555

BOZNIAK, E. G. \& L. L. KENNEDY. 1968. Periodicity and ecology of the phytoplankton in an oligotrophic and eutrophic lake. Canadian Journal of Botany, 46: 1259-1271. DOI: 10.1139/b68-168

DE HOYOS, C. 1996. Limnología del Lago de Sanabria. Variabilidad interanual del fitoplancton. Ph.D. Thesis. University of Salamanca, Spain.

DE HOYOS, C., J. J. ALDASORO, M. TORO \& F. A. COMÍN. 1998. Specific composition and ecology of chrysophyte flagellates in Lake Sanabria (NW Spain). Hydrobiologia, 369/370: 287-295. DOI: $10.1023 / \mathrm{A}: 1017044908663$

DE HOYOS, C. \& F. A. COMÍN. 1999. The importance of inter-annual variability for management. Hydrobiologia, 395/396: 281-291. DOI: 10.1023/A:1017030526231

DESCY, J. P., M. A. HARDY, S. STÉNUITE, S. PIRLOT, B. LEPORCQ, I. KIMIREI, B. SEKADENDE, S. R. MWAITEGA \& D. SINYENZA. 2005. Phytoplankton pigments and community composition in Lake Tanganyika. Freshwater Biology, 50: 668-684. DOI: 10.1111/j.1365-2427.2005.01358.x

DESCY, J. P., H. SARMENTO \& H. W. HIGGINS. 2009. Variability of phytoplankton pigment ratios across aquatic environments. European Journal of Phycology, 44: 319-330. DOI: $10.1080 / 09670260802618942$

[EC] European Comission, Parliament and Council. 2000. Directive 2000/60/EC of the European Parliament and of the Council of 23 October 2000 Establishing a Framework for Community Action in the Field of Water
Policy. The European Parliament and the Council of the European union, Luxembourg. PE-CONS 3639/1/100 Rev.1.

FELIP, M. \& J. CATALAN. 2000. The relationship between phytoplankton biovolume and chlorophyll in a deep oligotrophic lake: decoupling in their spatial and temporal maxima. Journal of Plankton Research, 22 (1): 91-106. DOI: 10.1093/plankt/22.1.91

FIETZ, S. \& A. NICKLISCH. 2004. An HPLC analysis of the summer phytoplankton assemblage in Lake Baikal. Freshwater Biology, 49: 332-345. DOI: 10.1111/j.1365-2427.2004. 01183.x

GOERICKE, R. \& J. P. MONTOYA. 1998. Estimating the contribution of microalgal taxa to chlorophyll $a$ in the field, variations of pigment ratios under nutrient and light-limited growth. Marine Ecology Progress Series, 169: 97-112. DOI: 10.3354/meps 169097

GUILLARD, R. R. L. \& J. H. RYTHER. 1962. Studies of marine planktonic diatoms. I. Cyclotella nana Hutedt and Detonula confervacea Cleve. Canadian Jouornal of Microbiology, 8: 229-239. DOI: 10.1139/m62-029

GUILLÉN, A. 2015. Lago de Sanabria 2015, presente y futuro de un ecosistema en desequilibrio. Logroño, Spain.

HOU, Y., W. LIANG, L. ZHANG, S. CHENG \& F. HE. 2011. Freshwater algae chemotaxonomy by high-performance liquid chromatographic (HPLC) analysis. Frontiers of Environmental Science \& Engineering, 5: 84-91. DOI: $10.1007 / \mathrm{s} 11783-010-0283-1$

JÄGER, C. G., S. DIEHL \& G. M. SCHMIDT. 2008. Influence of water column depth and mixing on phytoplankton biomass, community composition, and nutrients. Limnology and Oceanography, 53: 2361-2373. DOI: 10.4319/ 10.2008.53.6.2361

JAMBRINA-ENRÍQUEZ, M., M. RICO, A. MORENO, M. LEIRA, P. BERNÁRDEZ, R. PREGO, C. RECIO \& B. L. VALEROGARCÉS. 2014. Timing of deglaciation and postglacial environmental dynamics in NW Iberia: the Sanabria Lake record. Quaternary Science Reviews, 94: 136-58. DOI: 10.1016/j. quascirev.2014.04.018

JEFFREY, S. W. 1997. Chlorophyll and carote- 
noid extinction coefficients. In: Phytoplankton Pigments in Oceanography: guidelines to modern methods. Jeffrey, S. W., R. F. C. Mantoura \& S. W. Wright, (Eds.): 598-596. UNESCO Publishing.

JEFFREY, S. W., S. W. WRIGHT \& M. ZAPATA. 1999. Recent advances in HPLC pigment analysis of phytoplankton. Marine and Freshwater Research, 50: 879-896. DOI: 10.1071/MF99109

LINDENSCHIMDT, K. E. \& I. CHORUS. 1998. The effect of water column mixing on phytoplankton succession, diversity and similarity. Journal of Plankton Research, 20 (10): 1927-51. DOI: 10.1093/plankt/20.10.1927

LUQUE, J. A. \& R. JULIA. 2002. Lake sediment response to land-use and climate change during the last 1000 years in the oligotrophic Lake Sanabria (northwest of Iberian Peninsula). Sedimentary Geology, 148 (1-2): 343-55. DOI: 10.1016/S0037-0738(01)00225-1

MARGALEF, R. 1955. Comunidades dulceacuícolas del NW de España. Publicaciones del Instituto de Biología Aplicada, 21: 5-31.

NEGRO, A. I., C. DE HOYOS \& J. C. VEGA. 2000. Phytoplankton structure and dynamics in Lake Sanabria and Valparaíso reservoir (NW Spain). Hydrobiologia, 424: 25-37. DOI: 10.1023/A:1003940625437

NEGRO, A. I., C. DE HOYOS \& J. J. ALDASORO. 2003. Diatom and desmid relationships with the environment in mountain lakes and mires of NW Spain. Hydrobiologia, 505: 1-13. DOI: 10.1023/B:HYDR.0000007212.78065.c1

OECD, 1982. Eutrophication of waters, monitoring, assessment and control. OECD, Paris, France.

OLENINA, I., S. HAJDU, L. EDLER, A. ANDERSSON, N. WASMUND, S. BUSCH, J. GÖBEL, S. GROMISZ, S. HUSEBY, M. HUTTUNEN, A. JAANUS, P. KOKKONEN, I. LEDAINE \& E. NIEMKIEWICZ. 2004. Biovolumes and size-classes of phytoplankton in the Baltic Sea. XX Baltic Sea Environment Proceedings. Helsinki Commission.

OLSÉN, P. \& E. WILLÉN. 1980. Phytoplankton response to sewage reduction in Vättern, a large oligotrophic lake in Central Sweden. Archiv fur Hydrobiologie, 89: 171-188.
PADISÁK, J., G. BORICS, I. GRIGORSZKY \& É. SORÓCZKI-PINTÉR. 2006. Use of phytoplankton assemblages for monitoring ecological status of lakes within the Water Framework Directive: the assemblage index. Hydrobiologia, vol. 621, no. 1, 2009, pp. 1-19. DOI: 10.1007/s10750-008-9645-0

PAHISSA, J., C. FERNÁNDEZ-ENRÍQUEZ \& C. DE HOYOS. 2015. Water quality of Lake Sanabria according to phytoplankton. A comparison with historical data. Limnetica, 34 (2): 527-540. DOI: 10.23818/limn.34.39

PASZTALENIEC, A. \& M. PONIEWOZIK. 2010. Phytoplankton based assessment of the ecological status of four shallow lakes (Eastern Poland) according to Water Framework Directive, a comparison of approaches. Limnologica, 40: 251-259. DOI: 10.1016/j.limno. 2009.07.001

PICAZO, A., C. ROCHERA, E. VICENTE, M. R. MIRACLE \& A. CAMACHO. 2013. Spectrophotometric methods for the determination of photosynthetic pigments in stratified lakes: a critical analysis based on comparisons with HPLC determinations in a model lake. Limnetica, 32(1): 139-157.

REYNOLDS, C. S. 1987. Phytoplankton periodicity, the interactions of form, function and environmental variability. Freshwater Biology, 14: 111-142. DOI: 10.1111/j.1365-2427. 1984.tb00027.x

REYNOLDS, C. S. 2000. Phytoplankton designer-or how to predict compositional responses to trophic-state change. Hydrobiologia, 424: 123-132. DOI: 10.1023/A:1003913330889

RICO, M., B. VALERO-GARCÉS, J. C. VEGA, A. MORENO, P. GONZÁLEZ-SAMPÉRIZ, M. MORELLÓN \& P. MATA. 2007. El registro sedimentario del Lago de Sanabria desde la última glaciación. Resúmenes XII Reunión Nacional de Cuaternario. Junio 21-23, 2007. Ávila., Spain.

SEOANE S., W. EIKREM, R. PIENAAR \& B. EDVARDSEN. 2009. Chrysochromulina palpebralis sp. nov. (Prymnesiophyceae): a haptophyte, possessing two alternativemorphologies. Phycologia, 48: 165-176. DOI: 10.2216/08-63.1

SIMMONS, L. J., C. D. SANDGREN \& J. A. 
BERGES. 2016. Problems and pitfalls in using HPLC pigment analysis to distinguish Lake Michigan phytoplankton taxa. Journal of Great Lakes Research, 42: 397-404. DOI: 10.1016/j.jglr.2015.12.006

TABOADA, J. 1913. El Lago de San Martin de Castañeda. Boletín de la Real Sociedad Española de Historia Natural, 13: 960-986.

TRIGO, R. M., T. J. OSBORN \& J. M. CORTE-REAL. 2002. The North Atlantic Oscillation influence on Europe: climate impacts and associated physical mechanisms. Climate Research, 20: 9-17. DOI: 10.3354/ cr020009

TRIGO, R. M., D. POZO-VÁZQUEZ, T. J. OSBORN, Y. CASTRO-DÍEZ, S. GÓMIZFORTIS \& M. J. ESTEBAN-PARRA. 2004. North Atlantic Oscillation influence on precipitation, river flow and water resources in the Iberian Peninsula. International Journal of Climatology, 24: 925-944. DOI: 10.1002/joc. 1048

UTERMÖHL, H. 1958. Zur Vervollkommnung der quantitativen Phytoplankton Methodik. Mitteilungen der internationale Vereinigung der theoretische und angewandte Limnologie, 5: 567-596. DOI: 10.1080/05384680.1958. 11904091

VAN DEN WYNGAERT, S., M. MÖST, R. FREIMANN, B. W. IBELINGS \& P. SPAAK. 2015. Hidden diversity in the freshwater planktonic diatom Asterionella formosa. Molecular Ecology, 24: 2955-2972. DOI: 10.1111/mec. 13218

VEGA, J. C., C. DE HOYOS \& J. J. ALDASORO. 1992. The Sanabria lake. The largest natural freshwater lake in Spain. Limnetica, 8: 49-57

VEGA, J. C., C. DE HOYOS, J. J. ALDASORO,
J. DE MIGUEL \& H. FRAILE. 2005. Nuevos datos morfométricos para el Lago de Sanabria. Limnetica, 24 (1-2): 115-122.

VISBECK, M. H., J. W. HURRELL, L. POLVANI \& H. M. CULLEN. 2001. The North Atlantic Oscillation: past, present, and future. Proceedings of the National Academy of Sciences, 98: 876-12 877. DOI: 10.1073/pnas. 231391598

WEYHENMEYER, G. A. 2001. Warmer winters: are planktonic algal populations in Sweden's largest lakes affected? AMBIO, 30: 565-571. DOI: 10.1579/0044-7447-30.8.565

WEYHENMEYER, G. A., R. ADRIAN, U. GAEDKE, D. M. LIVINGSTONE \& S. C. MABERLY. 2002. Response of phytoplankton in European lakes to a change in the North Atlantic Oscillation. Verhandlungen Internationale Vereinigung für Theoretische und Angewandte Limnologie, 20: 1436-1439. DOI: $10.1080 / 03680770.2001 .11902692$

YANG, X., X. WU, H.L.HAO \& Z. L. HE. 2008. Mechanisms and assessment of water eutrophication. Journal of Zhejiang University Science B, 9 (3): 197-209. DOI: 10.1631/jzus. B0710626

ZAPATA, M. \& J. L. GARRIDO. 1991. Influence of injection conditions in reversed-phase high performance liquid chromatography of chlorophylls and carotenoids. Chromatographia, 31 : 589-594. DOI: 10.1007/BF02279480

ZAPATA, M., F. RODRÍGUEZ \& J. L. GARRIDO. 2000. Separation of chlorophylls and carotenoids from marine phytoplankton: a new HPLC method using a reversed phase C-8 column and pyridine-containing mobile phases. Marine Ecology Progress Series, 195: 29-45. DOI: $10.3354 /$ meps 195029

Con el patrocinio de:

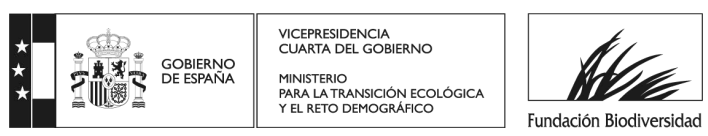

